\title{
PENGARUH GOOD CORPORATE GOVERNANCE DAN \\ VOLUNTARY DISCLOSURE TERHADAP BIAYA UTANG (STUDI EMPIRIS PADA PERUSAHAAN GO PUBLIC PERINGKAT 10 BESAR YANGTERDAFTAR DI CGPI TAHUN (2012 - 2016)
}

The Influence Of Good Corporate Governance And Voluntary Disclosure To The Cost Of Debt

(Empirical Study On The Top 10 Public Listed Companies Listed In CGPI 2012 2016)

Dewi Putri Andriani, Yulia Syafitri, Sunreni

Akuntansi, Ekonomi, Universitas Ekasakti, Padang, Sumatera Barat e-mail : dewiputriandriani008@gmail.com sunreni1404@gmail.com

\begin{abstract}
ABSTRAK
Penelitian ini bertujuan untuk mengetahui dan menguji pengaruh good corporate governance, dan voluntary disclosure terhadap biaya utang (studi empirispada perusahaan Go Public peringkat 10 besar yang terdaftar di CGPI tahun 2012-2016). Biaya utang diukur dengan tingkat bunga biaya utang, good corporate governance diukur menggunakan lima proksi yaitu kepemilikan institusional, kualitas audit, komisaris independen, ukuran dewan direksi dan frekuensi pertemuan komite audit, dan voluntary disclosure diukur menggunakan indeks voluntary disclosure. Hasil pengujian membuktikan bahwa (1) kepemilikan institusional tidak berpengaruh signifikan terhadap biaya utang, (2) kualitas audit tidak berpengaruh signifikan terhadap biaya utang, (3) frekuensi pertemuan komite audit tidak berpengaruh signifikan terhadap biaya utang, (4) ukuran dewan direksi berpengaruh signifikan terhadap biaya utang, (5) komisaris independen berpengaruh signifikan negatif terhadap biaya utang, (6) voluntary disclosure tidak berpengaruh signifikan terhadap biaya utang.
\end{abstract}

Kata kunci: Biaya Utang, Good Corporate Governance, dan Voluntary

Disclosure 


\begin{abstract}
ABSRACT
This study aims to determine and examine the effect of good corporate governance and voluntary disclosure on the cost of debt. Debt costs are measure by the interest cost of debt, good corporate governance is measured using five proxies, namely intitutional ownership, audit quality, independent commissioners, board of directors size and frequency of audit committe meetings, and voluntary disclosure measured using index voluntary disclosure. The test result provide evidence that institutional ownership does not significantly affect debt costs, a does not significantly affect debt costs udit quality, the frequency of audit committe meetings does not significantly affect debt costs, the size of the board of direktors has a significant effect on debt costs, independent commissioners have a significant negative effect on debt costs, and voluntary disclosure does not significantly affect debt costs

Keyword : cost of debt, good corporate governance, and voluntary disclosure
\end{abstract}




\section{PENDAHULUAN}

Perusahaan memiliki beberapa alternatif dalam melakukan pendanaan, dimana salah satunya adalah dengan menggunakan hutang. Hutang merupakan salah satu cara memperoleh dana dari pihak eksternal yaitu kreditor. Dana yang diberikan oleh kreditor dalam hal pendanaan terhadap perusahaan tersebut menimbulkan biaya hutang bagi perusahaan. Menurut Fabozzi dalam Juniarti (2009), biaya utang dapat didefinisikan sebagai tingkat yang harus diterima dari investasi untuk mencapai tingkat pengembalian (yield rate) yang dibutuhkan oleh kreditur atau dengan kata lain adalah tingkat pengembalian yang dibutuhkan oleh kreditur saat melakukan pendanaan dalam suatu perusahaan.

Disisi lain investor memerlukan pengungkapan yang memadai untuk menjamin apakah investasinya memiliki rasio yang sesuai dengan apa yang diperkirakan.Penelitian Asbaugh et. Al. dalam Juniarti dan Silviana (2014) bahwa perusahaan dengan good corporate governance yang kuat ternyata memiliki peringkat kredit (credit ratings) yang lebih tinggi dibandingkan dengan perusahaan dengan good corporate governance yang lemah. Dengan sistem good corporate governance yang kuat dapat membuat para investor dan kreditor percaya kepada perusahaan kita, karena penerapan good corporate governance yang kuat membuktikan bahwa terdapat pengelolaan manajemen yang baik sehingga resiko yang diterima oleh para investor dan kreditor pun semakin kecil. Itulah sebabnya bahwa dengan good corporate governance yang kuat akan mendapatkan keuntungan berupa biaya utang (cost of debt) yang rendah.

Forum for Corporate Governance in

Indonesia dalam Marichel (2016) merumuskan corporate governance sebagai sistemtata kelola perusahaan yang menjelaskan hubungan antara berbagai partisipan dalam perusahaan yang menentukan arah dan kinerja perusahaan. The Indonesian Institute of Corporate Governance (IICG) dalam Widya dan Marichel (2016) mendefinisikan Corporate Governance sebagai proses dan struktur yang diterapkan dalam menjalankan perusahaan, dengan tujuan utama meningkatkan nilai pemegang saham dalam jangka panjang, dengan tetap memperhatikan kepentingan stakeholder yang lain. Pengukuran good corporate governance diproksikan dengan corporate governance perception index (CGPI).

Disisi lain ketentuan bahwa perusahaan harus menyampaikan pengungkapan seluas - luasnya atas laporan keuangan telah mendorong perusahaan perusahaan untuk menyampaikan disclosure yang melampaui yang disyaratkan oleh standar atau yang dikenal dengan voluntary disclosure. Menurut Suwardjono (2014) mendefiniskan pengungkapan sukarela sebagai pengungkapan yang dilakukan perusahaan di luar apa yang diwajibkan oleh standar akuntansi atau peraturan pengawas.

Menurut Sengupta dalam R. Lanny dan Silviana (2014), memberikan bukti bahwa perusahaan yang memiliki rating disclosure quality yang tinggi dari para analis keuangan, akan menikmati interest cost of issuing debt yang lebih rendah. Ia menyimpulkan bahwa perusahaan yang memiliki cost of debt yang rendah, dinilai dari kualitas disclosure yang tinggi. Perusahaan yang melakukan pengungkapan sukarela (voluntary disclosure) merupakan perusahaan dengan tingkat transparansi yang tinggi. Transparansi suatu perusahaan pun dinilai akan mengurangi resiko, maka biaya utang (cost of debt) yang diterima pun semakin kecil.

Pada kasus perusahaan Unilever Indonesia Tbk. yaitu perusahaan go public peringkat 10 yang terdaftar di CGPI, pada tahun 2013Unilever Indonesia Tbk. berada diperingkat ke-5 dengan biaya utang sebesar $0,4 \%$ dari pinjaman yang didapatkan, sedangkan pada tahun 2014Unilever Indonesia Tbk. berada diperingkat ke-3 dengan biaya utang sebesar 1,9\% dari pinjaman yang didapatkan. Pada kasus Unilever Indonesia Tbk. dengan good corporate governance dan voluntary disclosure yang kuat atau berada pada peringkat ke-3 tahun 2014, perusahaan menerima biaya utang yang tinggi. Sedangkan pada saat good corporate governance dan voluntary disclosurenya agak melemah atau berada diperingkat ke-5, perusahaan menerima biaya utang yang rendah dari tahun sebelumnya pada saat berada diperingkat ke-3.

Berdasarkan latar belakang di atas tujuan dari penelitian ini adalah untuk mendapatkan bukti secara empiris mengenai pengaruh good corporate governance dan voluntary disclosure terhadap biaya utang secara parsial maupun secara simultan. 


\section{TINJAUAN PUSTAKA}

\subsection{Good Corporate Governance}

The Indonesian Institute of Corporate Governance (IICG) dalam Widya dan Marichel (2016) mendefinisikan Corporate Governance sebagai proses dan struktur yang diterapkan dalam menjalankan perusahaan, dengan tujuan utama meningkatkan nilai pemegang saham dalam jangka panjang, dengan tetap memperhatikan kepentingan stakeholder yang lain.

Menurut Komite Nasional Kebijakan Corporate Governance (KNKCG) dalam Danang (2013), "Good Corporate Governance adalah suatu proses dari struktur yang digunakan oleh organ perusahaan guna memberikan nilai tambah pada perusahaan secara berkesinambungan dalam jangka panjang bagi pemegang saham dengan tetap memperlihatkan kepentingan stakeholder lainnya, berlandaskan peraturan perundang undangan dan norma yang berlaku".

Berdasarkan pengertian di atas, good corporate governance didefinisikan sebagai suatu sistem pengendalian internal perusahaan yang memiliki tujuan utama untuk meningkatkan nilai pemegang saham dalam jangka panjang, dengan tetap memperhatikan kepentingan stakeholder yang lain.

\subsubsection{Pengukuran Good Corporate Governance \\ Good corporate governance} dalam penelitian ini akan diukur dengan menggunakan lima proksi dari Marichel (2016) sebagai berikut :

1. Kepemilikan Institusional

Menurut Juniarti dan Marichel (2016) kepemilikan institusional merupakan presentase kepemilikan perusahaan yang dimiliki oleh investor institusional seperti pemerintah, perusahaan investasi, bank perusahaan asuransi maupun kepemilikan lembaga dan perusahaan lain. Menurut

Menurut Fury dalam Pujiati (2015), kepemilikan institusional dihitung dengan rumus sebagai berikut

\section{Kualitas Audit Menurut}

Arens

(2012), mendefiniskan audit sebagai pengumpulan dan evaluasi bukti mengenai informasi untuk menentukan dan melaporkan derajat kesesuaian antara informasi tersebut dengan kriteria yang telah ditetapkan.
Arens (2012), menjelaskan bahwa di Indonesia empat KAP terbesar disebut kantor akuntan publik internasional "Empat Besar" atau di kenal sebagai KAP big-four. Menurut Wisnu dalam Rahmawelly (2014), adapun yang termasuk KAP big-fouradalah :

a. KAP Purwantono, Sarwoko, Sandjaja affiliate of Ernst \& Young

b. KAP Osman Bing Satrio - affiliate of Deloitte Touche Tomatsu

c. KAP Sidharta, Sidharta, Widjaja affiliate of KPMG

d. KAP Haryanto Sahari - affiliate of PwC.

3. Komisaris Independen

Komite Nasional Kebijakan

Governance (KNKG) dalam Nugroho (2014), menyatakan bahwa komisaris independen adalah anggota dewan komisaris yang tidak terafiliasi dengan manajemen, anggota komisaris lainnya, dan pemegang saham mayoritas, serta bebas dari hubunga bisnis dan/atau hubungan lainnya yang dapat mempengaruhi kemampuannya untuk bertindak independen atau semata - mata demi kepentingan perusahaan.

Menurut Prasojo dalam Rahmawati (2015), proporsi komposisi komisaris independen merupakan rasio antara jumlah komisaris yang berasal dari luar perusahaan atau tidak berasal dari pihak yang terafiliasi terhadap total dewan komisaris perusahaan. Dapat dirumuskan sebagai berikut :

\section{Ukuran Dewan Direksi}

Menurut UU No. 40 Tahun 2007 dalam Marichel (2016) tentang Perseroan Terbatas, dewan direksi adalah organ perseroan yang berwenang dan bertanggungjawab penuh atas pengurusan perseroan untuk kepentingan, sesuai dengan maksud dan tujuan perseroan serta mewakili perseroan, baik di dalam maupun di luar pengadilan sesuai dengan ketentuan anggaran dasar.

Menurut Jati dan Akhirson dalam Marichel (2016), ukuran dewan direksi diukur dengan jumlah dewan direksi suatu perusahaan. Persamaannya sebagai berikut :

$$
\text { DIR = Jumlah Dewan Direksi }
$$

5. Frekuensi Pertemuan Komite Audit Menurut FCGI dalam Amiruddin dan Marichel (2016) komite audit biasanya perlu mengadakan pertemuan tigasampai empat kali dalam satu tahun untuk melaksanakan kewajiban dan tanggungjawabnya. Pertemuan tersebut diselenggarakan, (1) sebelum 
dilakukannya audit tahunan; (2) sesudah pelaksanaan audit dan sebelum laporan keuangan dikeluarkan; dan (3) sebelum rapat umum pemegang saham tahunan.

Menurut Nugroho dan Meiranto dalam Marichel (2016), frekuensi pertemuan komite audit diukur dengan jumlah rapat komite audit dalam satu tahun. Persamaannya sebagai berikut :

FREK = Jumlah Rapat Komite Audit Dalam Satu Tahun

\subsection{Voluntary Disclosure}

Menurut Suwardjono (2014) secara konseptual, pengungkapan merupakan bagian integral dari pelaporan keuangan.Tujuan pengungkapan secara umum adalah memberikan informasi yang dipandang perlu untuk mencapai tujuan pelaporan keuangan dan untuk melayani berbagai pihak yang mempunyai kepentingan yang berbeda.

Menurut Chariri, dalam Hardiningsih dan Wahyuni (2013), pengungkapan (disclosure) berarti memberikan data yang bermanfaat kepada pihak yang memerlukan, dalam hal ini stakeholder. Dalam laporan keuangan, disclosure mengandung arti bahwa laporan keuangan harus memberikan informasi dan penjelasan yang cukup mengenai hasil aktivitas suatu unit usaha.Meek et.al.dalam Yesi (2015), menyebutkan bahwa pengungkapan sukarela merupakan pengungkapan bebas, dimana manajemen dapat memilih jenis informasi yang akan diungkapkan yang dipandang relevan untuk mengambil keputusan bagi pihak - pihak pemakainya. Sedangkan

menurut Suwardjono(2014) mendefiniskan pengungkapan sukarela sebagai pengungkapan yang dilakukan perusahaan di luar apa yang diwajibkan oleh standar akuntansi atau peraturan pengawas. Manajer perusahaan lebih banyak mengetahui informasi tentang kinerja perusahaan, baik saat ini maupun di masa yang akan datang dibandingkan dengan pihak eksternal perusahaan. Pengungkapan informasi oleh manajer tersebut selain dari pengungkapan wajib merupakan pilihan bebas yang dapat diambil oleh manajer.Manajer memiliki kemungkinan untuk menyembunyikan informasi yang tersedia jika informasi tersebut merupakan bad news atau tidak menguntungkan.

\subsubsection{Pengukuran Voluntary Disclosure}

Berdasarkan surat keputusan Bapepam No.06/PM/2000 dalam James (2013), luas pengungkapan wajib diukur dengan menggunakan 79 item pengungkapan, sedangkan luas pengungkapan sukarela diukur berdasarkan item pengungkapan sukarela dari laporan tahunan yang dikembangkan berdasarkan literatur ( Susanto, 1992; Choi dan Mueller, 1992; Meek dkk, 1995; dalam Suripto dan James, 2013) item pengungkapan sukarela terdiri dari 46 item yang diungkap.

Menurut Botosan dan Wang et al. dalam Sandra dan Rahmawelly (2014), perhitungan indeks pengungkapan sukarela adalah sebagai berikut :

a) Memberi skor untuk setiap item pengungkapan dengan ketentuan nilai satu untuk item yang diungkapkan dan nol jika tidak diungkapkan.

b) Skor yang diperoleh setiap perusahaan dijumlahkan untuk mendapatkan skor total.

c) Menghitung indeks sukarela dengan rumus :

Keterangan :

$\mathrm{I}=$ Indeks pengungkapan sukarela

$\mathrm{n}=\sum$ skor item pengungkapan sukarela perusahaan sampel

$\mathrm{k}=\sum$ seluruh item pengungkapan sukarela

\subsection{Biaya Utang}

Menurut Fabozzi dalam Juniarti (2009), Biaya utang dapat didefinisikan sebagai tingkat yang harus diterima dari investasi untuk mencapai tingkat pengembalian (yield rate) yang dibutuhkan oleh kreditur atau dengan kata lain adalah tingkat pengembalian yang dibutuhkan oleh kreditur saat melakukan pendanaan dalam suatu perusahaan. Biaya utang meliputi tingkat bunga yang harus dibayar oleh perusahaan ketika melakukan pinjaman. Sedangkan menurut Singgih dalam Juniarti (2009), cost of debt adalah tingkat bunga sebelum pajak yang dibayar perusahaan kepada pemberi pinjamannya.

Ayub dalam Rahmawati (2015), alternatif lain untuk mengukur biaya utang adalah dengan menghitung besarnya bunga yang dibayarkan oleh perusahaan dalam periode satu tahun dibagi dengan jumlah pinjaman yang menghasilkan bungan tersebut 
(interest bearing debt). Hal ini mengingat bahwa perusahaan biasanya memiliki utang tidak hanya kepada satu pihak kreditur saja, melainkan ke beberapa pihak, dimana besar tingkat bunga yang ditetapkan masing masing tersebut berbeda - beda. Oleh karena itu,biaya utang dapat dihitung dengan menggunakan rata - rata tertimbang dari beban bunga yang harus dibayarkan oleh perusahaan diproporsikan terhadap pokok pinjaman yang menghasilkan bunga tersebut. Instrument utng ini dapat berupa utang bank (bank loan), obligasi, sewa guna usaha (leasing) dan utang lainnya.

Pittman dan Fortindalam Dwi dan Rahmawelly (2014), mengukur variabel cost of debt dari besarnya beban bunga perusahaan dalam suatu periode dibagi dengan jumlah rata - rata pinjaman jangka panjang dan jangka pendek yang menghasilkan bunga pinjaman selama tahun tersebut. Katarina dalam Rahmawelly (2014), menjelaskan bahwa biaya utang dapat dirumuskan sebagai berikut :

Dalam penelitian ini yang digunakan untuk menghitung biaya utang adalah sesuai dengan penelitian yang dilakukan oleh Rahmawelly (2014) dan Khalidah (2016). Menurut Pittman dan Fortin dalam Khalidah dan Rahmawelly (2016), yaitu dihitung dengan cara membagi beban bunga dengan rata - rata pinjaman jangka pendek dan jangka panjang. Dalam biaya utang ini tidak memperhatikan tingkat bunga dan jangka waktu pinjaman, maka dirumuskan sebagai berikut :

\subsection{Hipotesis}

Hipotesis adalah dugaan sementara yang dianggap benar namun diperlukan pengujian. Adapun hipotesis yang diajukan oleh peneliti sebagai berikut :

H1 : Diduga bahwa kepemilikan institusional berpengaruh terhadap biayautang

H2 : Diduga bahwa kualitas audit berpengaruh terhadap biayautang

H3 : Diduga bahwa komisaris independen berpengaruh terhadap biaya utang

H4 : Diduga bahwa ukuran dewan direksi berpengaruh terhadap biayautang

H05 : Diduga bahwa frekuensi pertemuan komite audit berpengaruh terhadap biayautang

H6 :Diduga bahwa voluntary disclosure berpengaruh terhadap biaya utang.
H7: Diduga bahwa secara simultan kepemilikan institusional, kualitas audit, komisaris independen, ukuran dewan direksi, frekuensi pertemuan komite audit dan voluntary disclosure berpengaruh terhadap biaya utang.

\section{METODE PENELITIAN}

\subsection{Jenis, Waktu dan Tempat Penelitian}

Dalam penelitian ini penulis menggunakan metode yang bersifat dokumentasi dengan jenis data kuantitatif. Penelitian ini dilakukan pada perusahaan $G o$ Public peringkat 10 Besar yang terdaftar di Corporate Governance Perception Index (CGPI) dan waktu penelitian ini adalah dari tahun 2012-2016.

\subsection{Populasi dan Sampel}

Populasi penelitian ini adalah perusahaan Go Public yang terdaftar di CGPI peringkat 10 besar tahun 2012 - 2016.yang terdiri dari 21 perusahaan.

Pengambilan sampel dalam penelitian ini dilakukan dengan teknik purposive sampling. Teknik porpusive sampling dilakukan dengan memilih sampel dengan tujuan tertentu secara subyektif peneliti sesuai kriteria - kriteria yang ditetapkan dan harus dipenuhi oleh sampel. Sampel dalam penelitian ini ada sebanyak 7 perusahaan.

\subsection{Jenis dan Sumber Data}

Dalam penyusunan skripsi ini peneliti menggunakan jenis data dokumentasi, dengan sumber data sekunder.

\subsection{Definisi Operasional Variabel}

\section{Variabel Terikat}

Variabel terikat (dependent variable) yaitu variabel dimana faktor keberadaannya dipengaruhi oleh viariabel bebas. Variabel terikat dalam penelitian ini adalah biaya utang. Biaya utang dalam penelitian ini dinyatakan dengan variabel COD (Cost Of Debt), yang diukur dengan :

\section{Variabel Bebas}

Variabel bebas (independent variable) yaitu variabel yang menjelaskan atau mempengaruhi variabel lain. Variabel bebas dalam penelitian ini sebagai berikut : 
a. Kepemilikan institusional (X1.1)

Menurut Wahyu dalam Pujiati (2015), kepemilikan institusional merupakan kondisi dimana institusi memiliki saham dalam suatu perusahaan. Institusi tersebut dapat berupa institusi pemerintah, institusi swasta, domestik maupun asing.

$$
\text { Menurut Fury dalam Pujiati }
$$

(2015), kepemilikan institusioanal dihitung denganr umus sebagai berikut :

b. Kualitas audit (X1.2)

De Angele dalam Pangestika dan Rahmawelly (2014), mendefinisikan kualitas audit sebagai probabilitas dimana seorang auditor menemukan dan melaporkan tentang adanya suatu pelanggaran dalam sistem akuntansi auditnya. Kualitas audit dalam penelitian ini akan diukur dengan apakah laporan keuangan perusahaan diaudit oleh KAP big- four atau tidak. Proksi ini menggunakan dummy variable yaitu dengan memberikan nilai 1 bila laporan keuangan perusahaan diaudit oleh KAP big-four dan nilai 0 bila laporan keuangan perusahaan diaudit oleh KAP lainnya.

Menurut Wisnu dalam Rahmawelly (2014), adapun yang termasuk KAP big-four adalah :

a. KAP Purwantono, Sarwoko, Sandjaja affiliate of Ernst \& Young

b. KAP Osman Bing Satrio - affiliate of Deloitte Touche Tomatsu

c. KAP Sidharta, Sidharta, Widjaja affiliate of KPMG

d. KAP Haryanto Sahari - affiliate of PwC.

c. Komisaris independen (X1.3)

Komite Nasional Kebijakan

Governance dalam Nugroho (2014), menyatakan bahwa komisaris independen adalah anggota dewan komisaris yang tidak terafiliasi dengan manajemen, anggota komisaris lainnya, dan pemegang saham mayoritas, serta bebas dari hubunga bisnis dan/atau hubungan lainnya yang dapat mempengaruhi kemampuannya untuk bertindak independen atau semata - mata demi kepentingan perusahaan. Dapat dirumuskan sebagai berikut :

\section{d. Ukuran Dewan Direksi (X1.4)}

Menurut UU No. 40 Tahun 2007 dalam Marichel (2016) tentangPerseroan Terbatas, dewan direksi adalah organ perseroan yang berwenang dan bertanggungjawab penuh atas pengurusan perseroan untuk kepentingan, sesuai dengan maksud dan tujuan perseroan serta mewakili perseroan, baik di dalam maupun di luar pengadilan sesuai dengan ketentuan anggaran dasar.

Menurut Jati dan Akhirson dalam Marichel (2016), ukuran dewan direksi diukur dengan jumlah dewan direksi suatu perusahaan. Persamaannya sebagai berikut :

DIR = Jumlah Dewan Direksi Perusahaan

e. Frekuensi Pertemuan Komite Audit (X1.5)

Menurut FCGI dalam Amiruddin dan Marichel (2016) komite audit biasanya perlu mengadakan pertemuan tigasampai empat kali dalam satu tahun untuk melaksanakan kewajiban dan tanggungjawabnya. Pertemuan tersebut diselenggarakan, (1) sebelum dilakukannya audit tahunan; (2) sesudah pelaksanaan audit dan sebelum laporan keuangan dikeluarkan; dan (3) sebelum rapat umum pemegang saham tahunan. Persamaannya sebagai berikut :

FREK = Jumlah Rapat Komite Audit Dalam Satu Tahun

f. Voluntary Disclosure (X2)

Menurut Suwardjono(2014) mendefiniskan pengungkapan sukarela sebagai pengungkapan yang dilakukan perusahaan di luar apa yang diwajibkan oleh standar akuntansi atau peraturan pengawas.Berdasarkan surat keputusan Bapepam No.06/PM/2000 dalam James (2013), luas pengungkapan wajib diukur dengan menggunakan 79 item pengungkapan, sedangkan luas pengungkapan sukarela diukur berdasarkan item pengungkapan sukarela dari laporan tahunan yang dikembangkan berdasarkan literatur ( Susanto, 1992; Choi dan Mueller, 1992; Meek dkk, 1995; dalam Suripto dan James, 2013) item pengungkapan sukarela terdiri dari 46 item yang diungkap.

Menurut Botosan (1997), Amuwarni (2006) dan Wang et al (2008) dalam Sandra dan Rahmawelly (2014), perhitungan indeks pengungkapan sukarela adalah sebagai berikut

a) Memberi skor untuk setiap item pengungkapan dengan ketentuan nilai satu untuk item yang diungkapkan dan nol jika tidak diungkapkan.

b) Skor yang diperoleh setiap perusahaan dijumlahkan untuk mendapatkan skor total.

c) Menghitung indeks sukarela dengan rumus : 


$$
-
$$

Keterangan :

I = Indeks pengungkapan sukarela

$\mathrm{n}=\sum$ skor item pengungkapan sukarela perusahaan sampel

$\mathrm{k}=\sum$ seluruh item pengungkapan sukarela 3.5 Metode Analisis Data

Metode analisis data yang digunakan dalam penelitian ini adalah sebagai berikut :

\section{a. Uji Asumsi Klasik}

Sebelum dilakukan pengujian regresi berganda, perlu dilakukan suatu pengujian asumsi klasik agar model regresi menjadi suatu model yang lebih representatif. Uji asumsi klasik yang digunakan pada penelitian ini adalah uji normalitas, uji multikolonieritas, uji autokolerasi, dan uji heteroskedastisitas.

\section{b. Analisis Deskriptif}

Menurut Ghozali (2012), statistik deskriptif memberikan gambaran atau deskripsi suatu data yang dilihat dari nilai rata - rata (mean), standar devisiasi, varian, maksimum, minimum, sum, range, kurtosis, dan skewness. Analisis deskriptif digunakan untuk menggambarkan dan mendeskripsikan variabel - variabel yang digunakan dalam penelitian.

\section{c. Analisis Regresi Linear Berganda}

Analisis regresi yang digunakan dalam penelitian ini adalah analisis regresi berganda. Menurut Agussalim (2015), regresi linear berganda adalah regresi dimana variabel terikatnya (Y) dihubungkan/dijelaskan lebih dari satu variabel $X$. Bentuk persamaan analisis regresi linear berganda adalah sebagai berikut :

$$
\begin{gathered}
Y=a+\beta 1 X 11+\beta 2 X 12+\beta 3 X 13+\beta 4 X 14+ \\
\beta 5 X 15+\beta 6 X 2+e i
\end{gathered}
$$$$
\text { Keterangan : }
$$

$\mathrm{Y}=$ Cost of debt

$\mathrm{X} 1.1=$ Kepemilikan Institusional

$\mathrm{X} 1.2=$ Kualitas Audit

$\mathrm{X} 1.3=$ Komisaris Independen

X1.4 = Ukuran Dewan Direksi

$\mathrm{X} 1.5=$ Frekuensi Pertemuan Komite Audit

$\mathrm{X} 2=$ Voluntary disclosure

a $=$ Konstanta

B1 =Koefsien Regresi Good Corporate Governance Dilihat Dari Kepemilikan Institusional Terhadap Biaya Utang

$\beta 2=$ Koefsien Regresi Good Corporate Governance Dilihat Dari Kualitas Audit Terhadap Biaya Utang

$\beta 3=$ Koefsien Regresi Good Corporate Governance Dilihat Dari Komisaris Independen Terhadap Biaya Utang $\beta 4=$ Koefsien Regresi Good Corporate Governance Dilihat Dari Ukuran Dewan Direksi Terhadap Biaya Utang

$\beta 5=$ Koefsien Regresi Good Corporate Governance Dilihat Dari Frekuensi Pertemuan Komite Audit Terhadap Biaya Utang

$\beta 6=$ Koefisien Regresi Voluntari ei $\quad=$ error terms

\section{d. Uji Koefisien Determinasi ( )}

Menurut Ghozali (2012), koefisien determinasi ( ) digunakan untuk mengetahui seberapa jauh kemampuan suatu model penelitian dalam menjelaskan variasi variabel dependen yang ada. Dengan demikian akan diketahui seberapa besar variabel dependen dapat diterangkan oleh variabel independen yang ada. Nilai yang mendekati angka 1 berarti variabel independen hampir atau mampu memberikan informasi yang dibutuhkan untuk memprediksi variasi dependen.

\subsection{Metode Pengujian Hipotesis}

Untuk melakukan pengujian hipotesis pada penelitian ini, dimana sebelumnya berdasarkan hipotesis yang telah dirumuskan kemudian harus diuji. Dalam penelitian ini akan dilakukan uji hipotesis diantaranya :

1. Uji Statistik t (t-test)

Menurut Ghozali (2012), uji ini dilakukan untuk mengetahui seberapa jauh variabel independen secara individu dalam menerangkan variabel dependen. Uji statistik $\mathrm{t}$ digunakan untuk mengetahui apakah ada perbedaan yang terjadi antara variabel variabel uji terhadap kelompok uji. Hipotesis dapat diterima atau ditolak dengan melihat kreteria sebagai berikut :

a. Jika nilai signifikansi lebih besar dari 0,05 maka hipotesis ditolak. Artinya bahwa tidak terdapat pengaruh yang signifikan antara variabel independen terhadap variabel dependen secara parsial.

b. Jika nilai sigifikansi lebih kecil dari 0,05 maka hipotesis diterima. Artinya bahwa terdapat pengaruh antara variabel independen terhadap variabel dependen secara parsial.

2. Pengujian Signifikan Model (F-test)

Menurut Ghozali (2012), uji F dilakukan untuk mengetahui apakah variabel dependen secara bersama-sama dipengaruhi oleh variabel independen. Pengujian dapat dilakukan dengan melihat tingkat signifikan F. 
Hipotesis dapat diterima atau ditolak dengan melihat kreteria sebagai berikut :

a. Jika nilai signifikansi lebih besar dari 5\% maka hipotesis ditolak. Artinya, bahwa tidak terdapat pengaruh yang signifikan secara bersama - sama antara variabel independen terhadap variabel dependen.

b. Jika nilai signifikansi lebih kecil dari 5\% maka hipotesis diterima. Artinya, bahwa terdapat pengaruh yang signifikan secara bersama - sama antara variabel independen terhadap variabel dependen.

\section{ANALISIS DAN PEMBAHASAN}

4.1 Pengujian dan Hasil Analisis data

1. Uji Asumsi Klasik

a. Uji Normalitas

Tabel 4.1

Hasil Uji Normalitas

One-Sample Kolmogorov-Smirnov Test

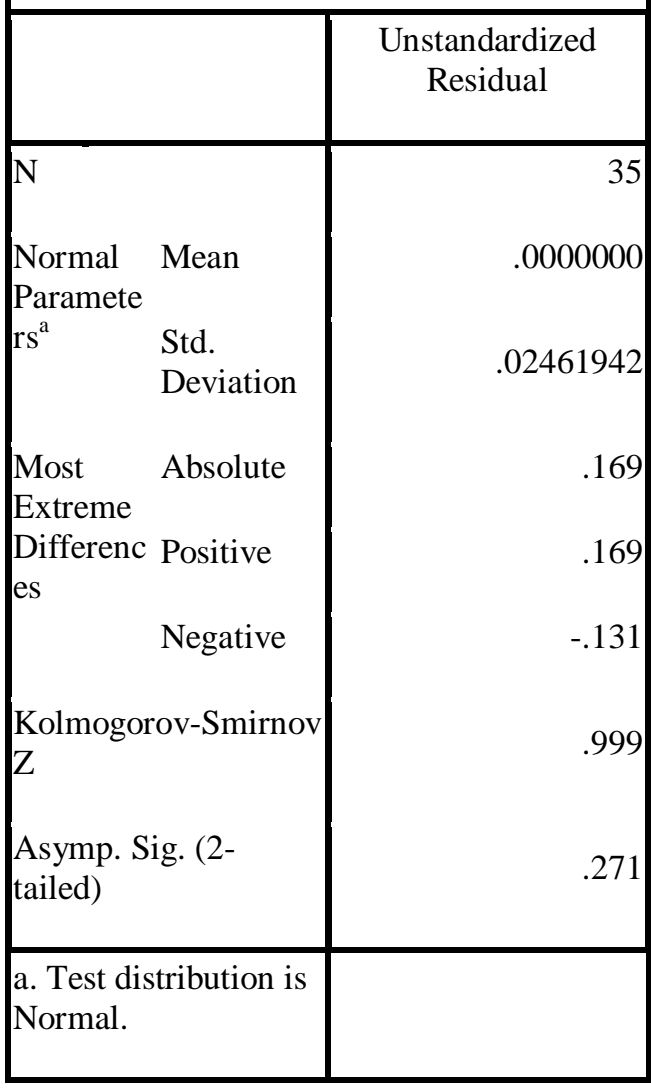

Sumber : Data sekunder diolah, 2018 b. Uji Autokorelasi

Tabel 4.2

Hasil Uji Autokorelasi

\begin{tabular}{|l|lr|}
\hline \multicolumn{2}{|c|}{ Model Summary $^{\mathbf{b}}$} \\
\hline Model & \multicolumn{2}{|c|}{ Durbin-Watson } \\
\hline 1 & & 1.150 \\
\hline
\end{tabular}

a. Predictors: (Constant), Voluntary

Disclosure, Komisaris Independen,

Kepemilikan Institusional, Kualitas Audit, Ukuran Dewan Direksi, Frekuensi

Pertemuan Komite Audit

b. Dependent Variable: Biaya Utang

Sumber : Data sekunder diolah, 2018

c. Uji Multikolinearitas

Tabel 4.3

Hasil Uji Multikolinearitas

\begin{tabular}{|c|c|c|}
\hline \multirow[b]{2}{*}{ Model } & \multicolumn{2}{|c|}{ Collinearity Statistics } \\
\hline & Tolerance & VIF \\
\hline 1 (Constant) & & \\
\hline INST & .107 & 9.354 \\
\hline KAUD & .823 & 1.215 \\
\hline DIRK & .694 & 1.441 \\
\hline FREK & .104 & 9.586 \\
\hline KIND & .776 & 1.288 \\
\hline VDIS & .920 & 1.087 \\
\hline
\end{tabular}

a. Dependent Variable: Biaya Utang

Sumber : Data sekunder diolah, 2018

d. Uji Heteroskedastisitas

Gambar 4.1

Hasil Uji Heteroskedastisitas

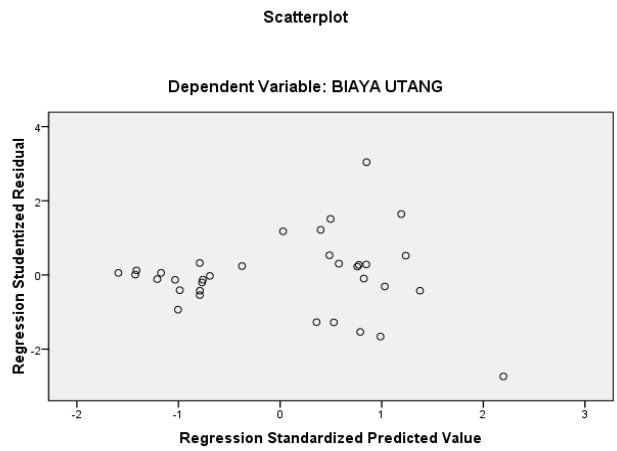

Sumber : Data sekunder diolah, 2018 
2.Analisis Regresi Linear Berganda

Tabel 4.4

Hasil Analisis Regresi Linear Berganda

\begin{tabular}{|c|c|c|}
\hline \multicolumn{3}{|c|}{ Coefficients $^{\mathrm{a}}$} \\
\hline \multirow[b]{2}{*}{ Model } & \multicolumn{2}{|c|}{ Unstandardized Coefficients } \\
\hline & B & Std. Error \\
\hline (Constant) & .014 & .072 \\
\hline INST & -.010 & .053 \\
\hline KAUD & .046 & .030 \\
\hline DIR & .008 & .003 \\
\hline FREK & .000 & .001 \\
\hline KIND & -.089 & .033 \\
\hline VDISC & -.069 & .083 \\
\hline
\end{tabular}

Sumber : Data sekunder diolah, 2018

Dari hasil analisis linear regresi berganda di atas, dapat diperoleh persamaan sebagai berikut :

$$
\begin{gathered}
\text { COD }=0,014-0,010 \text { INST }+0,046 \text { KAUD- } \\
0,089 \text { KIND }+0,008 \text { DIR }+0,000 \text { FREK }- \\
0,069 \text { VDISC }+ \text { e }
\end{gathered}
$$

3. Koefisien Determinasi (R Square)

Tabel 4.5

Hasil Uji Koefisien Determinasi

\begin{tabular}{|l|c|r|r|c|}
\hline \multicolumn{5}{|c|}{ Model Summary $^{\text {b }}$} \\
\hline Model & $\mathrm{R}$ & R Square & $\begin{array}{c}\text { Adjusted } \\
\text { R Square }\end{array}$ & $\begin{array}{c}\text { Std. Error } \\
\text { of the } \\
\text { Estimate }\end{array}$ \\
\hline 1 & $.610^{\mathrm{a}}$ & .372 & .237 & .02713 \\
\hline
\end{tabular}

a. Predictors: (Constant), Voluntary Disclosure, Komisaris Independen,Kepemilikan

Institusional, Kualitas Audit, Ukuran Dewan

Direksi, Frekuensi Pertemuan Komite Audit

b. Dependent Variable: Biaya Utang

Sumber : Data sekunder diolah, 2018
4. Uji t

\begin{tabular}{|c|c|c|c|c|}
\hline \multirow[b]{2}{*}{ Model } & $\begin{array}{l}\text { Unstandard } \\
\text { ized } \\
\text { Coefficient } \\
\text { s }\end{array}$ & \multirow[t]{2}{*}{$\mathrm{T}$} & \multirow[t]{2}{*}{ Sig. } & \multirow[t]{2}{*}{ Keterangan } \\
\hline & B & & & \\
\hline & .014 & .200 & .843 & \\
\hline INST & -.010 & -.179 & .859 & $\begin{array}{c}\text { Tidak } \\
\text { Signifikan }\end{array}$ \\
\hline $\begin{array}{l}\text { KAU } \\
\text { D }\end{array}$ & .046 & 1.516 & .141 & $\begin{array}{c}\text { Tidak } \\
\text { Signifikan }\end{array}$ \\
\hline DIR & .008 & 2.550 & .017 & Signifikan \\
\hline $\begin{array}{l}\text { FRE } \\
\mathrm{K}\end{array}$ & .000 & .432 & .669 & $\begin{array}{c}\text { Tidak } \\
\text { Signifikan }\end{array}$ \\
\hline KIND & -.089 & 2.724 & .011 & $\begin{array}{c}\text { Signifikan } \\
\text { Negatif }\end{array}$ \\
\hline $\begin{array}{l}\text { VDIS } \\
\mathrm{C}\end{array}$ & -.069 & -.840 & .408 & $\begin{array}{c}\text { Tidak } \\
\text { Signifiksn }\end{array}$ \\
\hline
\end{tabular}

Tabel 4.6

Hasil Uji t

a. Dependent Variable: Biaya Utang

Sumber : Data sekunder diolah, 2018

5. Uji F

Tabel 4.7

Hasil Uji F

\begin{tabular}{|c|l|l|l|l|l|}
\hline \multicolumn{6}{|c|}{ ANOVA $^{\mathbf{b}}$} \\
\hline Model & $\begin{array}{l}\text { Sum of } \\
\text { Squares }\end{array}$ & $\begin{array}{c}\text { Mean } \\
\text { Square }\end{array}$ & F & Sig. \\
\hline 1 Regression & .012 & 6 & .002 & 2.762 & $.031^{\mathrm{a}}$ \\
Residual & .021 & 28 & .001 & & \\
Total & .033 & 34 & & & \\
\hline
\end{tabular}

a. Predictors: (Constant), Voluntary Disclosure, Komisaris Independen, Kepemilikan Institusional, Kualitas Audit,Ukuran Dewan Direksi, Frekuensi Pertemuan Komite Audit b. Dependent Variable: Biaya Utang

\section{Sumber : Data sekunder diolah, 2018 \\ 5.KESIMPULAN DAN SARAN}

Penelitan ini digunakan untuk mengetahui pengaruh variabel good corporate governanceyang diproksikan dengan kepemilikan institusional, kualitas audit, komisaris independen, ukuran dewan direksi, dan frekuensi pertemuan komite audit, dan voluntary disclosure terhadap variabel dependen yaitu biaya utang pada perusahaan go public peringkat 10 besar yang terdaftar di CGPI tahun 2012 - 2016. Berdasarkan hasil penelitian, maka dapat diambil kesimpulan sebagai berikut :
1. Kepemilikan
institusional tidak berpengaruh signifikan terhadap biaya 
utang, hal ini ditinjau dari hasil analisis regresi linear berganda nilai coefficients sebesar $-0,010$ atau $-1,0 \%$. Kemudian dari uji t menunjukkan bukti dengan nilai $t_{\text {hitung }}$ sebesar $-0,179<\mathrm{t}_{\text {tabel }} 1,701(\mathrm{p}=0,859>$ 0,05). Maka dapat disimpulkan bahwa kepemilikan institusional tidak berpengaruh signifikan terhadap biaya utang.

2. Kualitas audit berpengaruh signifikan terhadap biaya utang, hal ini ditinjau dari hasil analisis regresi linear berganda nilai coefficients sebesar 0,046 atau $4,6 \%$. Kemudian dari uji $\mathrm{t}$ menunjukkan bukti dengan nilai $t_{\text {hitung }}$ sebesar 1,516 $<\mathrm{t}_{\text {tabel }}$ $1,701(\mathrm{p}=0,141>0,05)$. Maka dapat disimpulkan bahwa kualitas audit tidak berpengaruh signifikan terhadap biaya utang.

3. Komisaris independen berpengaruh signifikan negatif terhadap biaya utang, hal ini ditinjau dari hasil analisis regresi linear berganda nilai coefficients sebesar $-0,089$ atau $-8,9 \%$. Kemudian dari uji $t$ menunjukkan bukti dengan nilai $t_{\text {hitung }}$ sebesar $-2,724>\mathrm{t}_{\text {tabel }} 1,701(\mathrm{p}=0,011<$ 0,05). Maka dapat disimpulkan bahwa komisaris independen berpengaruh signifikan negatif terhadap biaya utang.

4. Ukuran dewan direksi berpengaruh signifikan terhadap biaya utang, hal ini ditinjau dari hasil analisis regresi linear berganda nilai coefficients sebesar 0,008 atau $0,8 \%$. Kemudian dari uji $t$ menunjukkan bukti dengan nilai $t_{\text {hitung }}$ sebesar 2,550 $>t_{\text {tabel }} 1,701(\mathrm{p}=0,017<$ 0,05). Maka dapat disimpulkan bahwa ukuran dewan direksi berpengaruh signifikan terhadap biaya utang.

5. Frekuensi pertemuan komite audit tidak berpengaruh terhadap biaya utang, hal ini ditinjau dari hasil analisis regresi linear berganda nilai coefficients sebesar 0,000 atau $0,0 \%$. Kemudian dari uji $\mathrm{t}$ menunjukkan bukti dengan nilai $t_{\text {hitung }}$ sebesar $0,432<t_{\text {tabel }} 1,701(\mathrm{p}=0,669>$ 0,05). Maka dapat disimpulkan bahwa frekuensi pertemuan komite audit tidak berpengaruh signifikan terhadap biaya utang.

6. Voluntary Disclosure tidak berpengaruh signifikan terhadap biaya utang, hal ini ditinjau dari hasil analisis regresi linear berganda nilai coefficients sebesar $-0,069$ atau $-6,9 \%$. Kemudian dari uji $t$ menunjukkan bukti dengan nilai $t_{\text {hitung }}$ sebesar $-0,840<\mathrm{t}_{\text {tabel }} 1,701(\mathrm{p}=0,408>$ 0,05). Maka dapat disimpulkan bahwa voluntary disclosurel tidak berpengaruh signifikan terhadap biaya utang.

7. Kepemilikan institusional, kualitas audit, ukuran dewan direksi, frekuensi pertemuan komite audit, komisaris independen dan voluntary disclosure secara bersama - sama berpengaruh terhadap biaya utang. Hal ini ditinjau dari hasil $\mathrm{F}$ hitung sebesar 2,762 dengan tingkat signifikansi probabilitasnya adalah 0,031 lebih kecil dari tingkat signifikan $\alpha=0,05$ atau tingkat signifikan uji F $0,031<0,05$.

\subsection{Saran}

Berdasarkan pembahasan dan kesimpulan di atas, maka dapat dikemukakan beberapa saran oleh peneliti sebagai berikut :

1. Bagi perusahaan yang diteliti dalam penelitian ini, praktek Good Corporate Governance khususnya dalam ukuran dewan direksi dan komisaris independen turut mempengaruhi biaya utang yang dikeluarkan perusahaan, dengan praktek good corporate governance khususnya dalam ukuran dewan direksi dan komisaris independen yang efektif dan optimal dapat mengakibatkan biaya utang perusahaan menjadi lebih rendah.

2. Bagi peneliti selanjutnya proksi untuk Corporate Governance dapat diperluas atau menggunakan indeks corporate governance yang lain.

3. Sebaiknya menggunakan item voluntary disclosure lain yang lebih mencerminkan tentang kondisi perusahaan yang sebenarnya untuk mengukur tingkat voluntary disclosure.

4. Bagi peneliti lain yang tertarik untuk meneliti judul yang sama, diharapkan untuk memperpanjang tahun penelitian, dan menambah jumlah sampel penelitian. 


\section{DAFTAR PUSTAKA}

Buku

Agussalim Manguluang, 2015. Statistik Lanjutan, Ekasakti Press, Padang

Sugiyono, 2014. Cara Mudah Menyusun Skripsi, Tesis dan Disertasi. Alfabeta, Bandung

Soewardjono, 2014. Teori Akuntansi Perekayasaan Pelaporan Keuangan Edisi Ketiga. Fakultas Ekonomi dan Bisnis, Universitas Gajah Mada

Sukrisno Agoes dan I Cenik Ardana, 2013. Etika Bisnis dan Profesi : Tantangan Membangun Manusia Seutuhnya. Salemba Empat, Jakarta

Ghozali Imam, 2012. Aplikasi analisis Multivariate dengan Program SPSS. Universitas Diponegoro, Semarang

Ross, Stephen A, 2010. Corporate Finance. McGraw-Hill, Boston

Arens Alvin A. et al, 2012. Jasa Audit Dan Assurance. Salemba Empat, Jakarta

Lukas Setia Atmaja, 2009. Manajemen Keuangan. Andi, Yogjakarta

FCGI, 2002. Peranan Dewan Komisaris dan Komite Audit dalam Pelaksanaan Corporate Governance (Tata Kelola Perusahaan). Jilid 2. FCGI, Jakarta

\section{Jurnal, Skripsi}

Fessy Febriyani, 2017. Pengaruh Struktur Corporate Governance (GCG) Terhadap Kinerja Keuangan. Skripsi, Fakultas Ekonomi Dan Bisnis. Universitas Lampung

Marichel, 2016. Pengaruh Good Corporate Governance Terhadap Biaya Modal. Skripsi. Fakultas Ekonomi dan Bisnis. Universitas Lampung

Pujiati, 2015. Pengaruh Kepemilikan Manajerial, Kepemilikan Institusional, Dan Kesempatan Investasi Terhadap Kebijaka Deviden Dengan Likuiditas Sebagai Variabel Pemoderasi. Skripsi, Fakultas Ekonomi, Universitas Negeri Yogyakarta
Yesi Wulandari, 2015. Analisis Faktor - Faktor Yang Mempengaruhi Luas Pengungkapan Informasi Sukarela Pada Laporan Keuangan Tahunan. Skripsi, Fakultas Ekonomi Dan Bisnis. Universitas Diponegoro

Yohana Heru Krisna Silviana, 2014. Pengaruh Tingkat Pengungkapan Antara Perusahaan Asing Dan Domestik Dengan Adanya Konvergensi IFRS. Skripsi, Fakultas Ekonomi. Universitas Atma Jaya Yogyakarta

Rahmawelly Yenibra, 2014. Pengaruh Corporate Governance, Kualitas Audit dan Voluntary Disclosure Terhadap Biaya Utang. Skripsi. Fakultas Ekonomi. Universitas Negeri Padang

Wahyuni Wijayanti, 2013. Analisis Pnegaruh Corporate Governance dan Karakteristik Perusahaan Terhadap Pengungkapan Sukarela (Voluntary Disclosure) Dalam Laporan Tahunan. Skripsi. Fakultas Ekonomi dan Bisnis. Universitas Islam Negeri Syarif Hidayatullah

Danang Febriyanto, 2013, Analisis Penerapan Good Corporate Governance (GCG) Terhadap Kinerja Perusahaan. Skripsi, Fakultas Ekonomi Dan Bisnis Universitas Islam Negeri Syarif Hidayatullah

James Tumewu dan Muliono, 2013. Faktor Faktor Yang Mempengaruhi Pengungkapan Kelengkapan Laporan Keuangan. Equilibrium, Vol. 11, No. 2. Universitas Wijaya Kusuma Surabaya

Nancy Yunita, 2012. Pengaruh Corporate Governance Terhadap Voluntary Disclosure Dan Biaya Utang. Jurnal Ilmiah Mahasiswa Akuntansi. Vol. 1, No. 1, Januari 2012

Etha Rizki Aryani, 2011. Pengaruh Good Corporate Governance Dan Struktur Kepemilikan Terhadap Agency Cost. Skripsi, Fakultas Ekonomi, Universitas Diponegoro

Dini Nur'aeni, 2010. Pengaruh Struktur Kepemilikan Saham Terhadap Kinerja 
Perusahaan. Skripsi, Fakultas Ekonomi, Universitas Diponegoro

Januarti, 2009. Pengaruh Good Corporate Governance dan Voluntary Disclosure Terhadap Biaya Utang. Jurnal Akuntansi dan Keuangan, Volume. II. No. 2, November 2009

\section{$\underline{\text { Internet }}$}

Http://www.swa.co.id

IICG, 2012. GCG Dalam Perspektif Risiko. http://www.iicg.org

PSAK No. 26 (revisi 2011), http://staff.blog.ui.ac.id/martani/files/ 2011/ED-PSAK-26-Biaya-Pinjaman.pdf

$\underline{\text { www.idx.co.id }}$ 